\title{
Aspects of the Establishment and Enforcement of Anti-Market Abuse Preventative Measures in the United States of America
}

\author{
Howard Chitimira \\ LLB LLM LLD \\ Lecturer, Faculty of Law, North-West University \\ E-mail:Howard.Chitimira@nwu.ac.za
}

\section{Doi:10.5901/mjss.2014.v5n7p253}

\begin{abstract}
The United States of America (the US) has to date successfully developed and adopted several distinct enforcement approaches and preventative measures to combat market abuse activities in all its capital and financial markets. For instance, apart from relying on civil, criminal and administrative penalties, the US anti-market abuse enforcement framework also employs a co-ordinated (joint) enforcement effort between the courts, self-regulatory organisations and the United States Securities and Exchange Commission (the SEC) at a federal level. Furthermore, other preventative measures such as private actions, public censure, bounty rewards and whistle-blower immunity are utilised to discourage and curb market abuse activities in the US. It is on this basis that this article will examine whether the integration of some of these US's anti-market abuse enforcement approaches and preventative measures will improve the enforcement of the market abuse prohibition in South Africa. To this end, selected preventative measures and enforcement approaches that are adopted in the US will be discussed and, where appropriate, contrasted with similar measures and/or enforcement methods in South Africa so as to identify and recommend possible enforcement approaches that could be incorporated in the South African anti-market enforcement framework. This is done by, first, discussing the co-operation between the SEC, the Department of Justice (the DOJ) and the courts. Secondly, the co-operation between the SEC and other selected self-regulatory organisations will be analysed. Lastly, the adoption and establishment of a good enforcement ethics culture in the US will be examined.
\end{abstract}

Keywords: market abuse, enforcement approaches, preventative measures, ethics, courts.

\section{Introduction}

The United States of America (the US) has to date successfully developed and adopted several distinct enforcement approaches and preventative measures to combat market abuse ${ }^{1}$ activities in all its capital and financial markets. ${ }^{2}$ For instance, apart from relying on civil, criminal and administrative penalties, the US anti-market abuse enforcement framework also employs a co-ordinated (joint) enforcement effort between the courts, self-regulatory organisations and the United States Securities and Exchange Commission (the SEC) at a federal level. ${ }^{3}$ Furthermore, other preventative measures such as private actions, public censure, bounty rewards and whistle-blower immunity are utilised to discourage and curb market abuse activities in the US. ${ }^{4}$ It is on this basis that this article will examine whether the integration of some of these US's anti-market abuse enforcement approaches and preventative measures will improve the enforcement of the market abuse prohibition in South Africa. ${ }^{5}$ To this end, selected preventative measures and enforcement

\footnotetext{
${ }^{I}$ Employed as a "generic term" referring to both insider trading and market manipulation in this article.

2 See generally Steinberg "Insider Trading Regulation-A Comparative Perspective" 2003 The International Lawyer 153 169-171.

${ }^{3}$ Steinberg 2003 The International Lawyer 169-171.

${ }^{4}$ Steinberg 2003 The International Lawyer 169-171. For further related comparative analysis in other countries, see Bhattacharya \& Daouk "The World Price of Insider Trading" 2002 Journal of Finance 75 75-108; Lyon \& Du Plessis The Law of Insider Trading in Australia (2005) 159-168; Avgouleas The Mechanics and Regulation of Market Abuse: A legal and Economic Analysis (2005) 75-502; Botha "Control of Insider Trading in South Africa: A Comparative Analysis" 1991 SA Merc LJ 1 1-18; Botha "Increased Maximum Fine for Insider Trading: A Realistic and Effective Deterrent?" 1990 SALJ $504-$ 508; Chitimira The Regulation of Insider Trading in South Africa: A Roadmap for an Effective, Competitive and Adequate Regulatory Statutory Framework (2008) LLM dissertation, University of Fort Hare, 41-72.

'See related discussion by Loubser "Insider Trading and other Market Abuses (Including the Effective Management of Price-sensitive Information)" in the Insider Trading Booklet final draft, (2006) 18-20; 24-27 <http:/www.jse.co.za/public/insider/JSEbooklet.pdf> (accessed 03-03-2014); the Johannesburg Stock Exchange Limited (the JSE) "Insider Trading and other Market Abuses (Including the Effective Management of Price-sensitive Information)" in the Insider Trading Booklet, (2013) 1-26 <http://www.jse.co.za/Libraries/JSE_Regulatory_Environment_Insider_Trading/InsiderTrading_Booklet.sflb.ashx> (accessed 03-03-2014); Chitimira A Comparative Analysis of the Enforcement of Market Abuse Provisions (2012) LLD thesis, Nelson Mandela Metropolitan University, 230-257; Van Deventer "Anti-Market Abuse Legislation in South Africa" (10-06-2008) 1-5 <http://www.fsb.co.za/public/marketabuse/FSBReport.pdfs (accessed 05-05-2013); Myburgh \& Davis "The Impact of South Africa's Insider Trading Regime:
} 
approaches that are adopted in the US will be discussed and, where appropriate, contrasted with similar measures and/or enforcement methods in South Africa so as to identify and recommend possible enforcement approaches that could be incorporated in the South African anti-market enforcement framework. This is done by, first, discussing the co-operation between the SEC, the Department of Justice (the DOJ) and the courts. Secondly, the co-operation between the SEC and other selected self-regulatory organisations will be analysed. Lastly, the adoption and establishment of a good enforcement ethics culture in the US will be examined.

\section{Co-operation between Enforcement Authorities and the Adoption of Adequate Preventative Measures}

\subsection{Co-operation between the SEC, the DOJ and the Courts}

The success and effectiveness of the US's market abuse regime has been attributed to a number of factors including inter alia the excellent co-operative enforcement effort of the SEC, DOJ and the courts. The SEC and the DOJ are mainly responsible for the civil and criminal enforcement of the market abuse prohibition respectively. ${ }^{6}$ The DOJ may prosecute all criminal cases of market abuse referred to it by the SEC. This prima facie indicates that there is some co-operation between the SEC and the DOJ. The competent courts in the US have, in most instances and on the advice of the SEC, successfully instituted criminal proceedings against the persons accused of committing market abuse offences. ${ }^{7}$

The DOJ revised its rules of engagement for pursuing suspected securities law offenders in 2003 and its focus was now mainly on improving the skills and expertise of prosecutors and other officials of the courts, especially with regard to the combating of corporate crimes such as market abuse. Furthermore, the DOJ revised its co-operation-credit policies to enhance co-operation with the SEC and to guide its members of staff on how to investigate, charge or prosecute securities law violations and market abuse cases referred to it by the SEC. ${ }^{8}$ The SEC further released its enforcement manual in $2008^{9}$ which, inter alia, seeks to increase the investigations and prosecutions of market abuse cases by both the DOJ and the SEC. This eventually improved the sharing of information between the SEC and the DOJ as well as the parallel enforcement of the market abuse prohibition in the US. ${ }^{10}$

Although the DOJ has the exclusive authority over the criminal enforcement of the federal securities laws, it often acts with the guidance and assistance from the SEC. In relation to this, the SEC's staff members are sometimes assigned to the DOJ or the courts to facilitate and help in the preparation of market abuse or other corporate criminal cases for trial. ${ }^{11}$ In South Africa, the FSB ${ }^{12}$ and the Director of Public Prosecutions (the DPP) are also responsible for the civil and criminal enforcement of the market abuse prohibition respectively. As is the position in the US, ${ }^{13}$ the DPP may prosecute criminal cases of market abuse that are referred to it by the FSB in South Africa. ${ }^{14}$ However, in contrast to the position in the US, ${ }^{15}$

\footnotetext{
A Report for the Financial Services Board" (25-03-2004) 8-33 <http://www.genesis-analytics.com/public/FSBReport.pdfs (accessed 09-02-2013); Chanetsa "Insider Trading is Notoriously Hard to Prosecute" Business Report 26 April 2004; Pretorius and Another v Natal South Sea Investment Trust 19653 SA 410 $(W)$, were the courts failed to convict the suspected insider trading offenders; Blincoe "Datatec Directors Pay Up on Insider Trading Charges" (2001) <http://www.theregister.co.uk/2001/05/23/datatec_directors_pay_up/> (accessed 03-03-2014), where two Datatec directors, Jens Montanana and Robin Rindel were reportedly fined about R1 million each for insider trading by the Financial Services Board (the FSB); Barron "Greg Draws a Blank in Belfort Parallel" (2014) <http:/www.timeslive.co.za/Feeds/2014/02/02/greg-draws-a-blank-in-belfort-parallel> (accessed 03-03-2014), where Greg Blank was reportedly sentenced to eight years imprisonment for stock market-related fraud and front running in 1992; Osode "The new South African Insider Trading Act: Sound law reform or legislative overkill?" 2000 Journal of African Law 239 239-263; Jooste "A critique of the insider trading provisions of the 2004 Securities Services Act" 2006 SALJ 437 441-460; Van Deventer "New watchdog for insider trading" 1999 FSB Bulletin 2 3; Beuthin \& Luiz Beuthin's Basic Company Law (2000) 235-238; Luiz "Market Abuse and the Enforcement Committee" 2011 SA Merc LJ 151-172; Luiz "Insider Trading Regulation - If at First You Don't Succeed..." 1999 SA Merc LJ 136 136-151; Henning \& Du Toit "The Regulation of False Trading, Market Manipulation and Insider Trading" 2000 Journal for Juridical Science 155 155-165 \& Osode "The Regulation of Insider Trading in South Africa: A Public Choice Perspective" 1999 African Journal of International and Comparative Law 688 688-708.

${ }^{6}$ The DOJ and/or the relevant courts are further required to prosecute any criminal cases involving market abuse in private litigation.

${ }^{7}$ See generally related remarks in paragraph 1 above; Steinberg 2003 The International Lawyer 169-171.

${ }^{8}$ Prior to this, the SEC released the so-called Seaboard Report in 2001 in order to inter alia improve the disclosure of information regarding the results of any investigation carried by itself or by the Department of Justice. Saikin "SEC, DOJ Clarify Cooperation" <http://www.executivelegaladvisor.com/docs/SECDOJ-Clarify-Cooperation.htm> (accessed 28-02-2014).

${ }^{9}$ This is commonly referred to as "the Red Book".

${ }^{10}$ Nevertheless, this co-operative relationship does not allow either the SEC or the DOJ to circumvent the enforcement actions employed by other regulatory bodies like the Commodity Futures Trading Commission (the CFTC).

${ }_{11}^{11}$ This clearly shows that the SEC and the DOJ have a good co-operative relationship towards the curbing and prevention of all possible federal securities law violations in the US. As a result the US has been fairly successful in investigating and prosecuting several securities law violations and market abuse cases to date.

${ }^{12}$ See $s 84$ read with s 82 of the Financial Markets Act 19 of 2012, hereinafter referred to as the Financial Markets Act.

${ }_{13}^{13}$ See related comments above.

${ }^{14}$ See generally s 84(10) of the Financial Markets Act.

${ }^{15}$ See related comments above.
} 
there is apparently little or minimal co-operation between the FSB and the DPP in South Africa. Put differently, the cooperative enforcement relationship between the FSB and the DPP has not been fully developed and utilised to increase and improve the criminal prosecution of market abuse cases in South Africa. ${ }^{16}$

\subsection{Co-operation between the SEC and other Self-Regulatory Organisations}

In order to curb illicit trading practices, the SEC has entered into several co-operative relationships with similar enforcement bodies both at a local and international level. ${ }^{17}$ The SEC supervises the regulation and enforcement of securities laws by the self-regulatory organisations in the US. ${ }^{18}$ The SEC has authority to approve, amend or revoke any rule or enforcement action imposed by the self-regulatory organisations. ${ }^{19}$ This could indicate that the SEC and the selfregulatory organisations have some co-operative relationship which focuses mainly on the enforcement of the federal securities laws to combat market abuse and other related illicit activities. ${ }^{20}$

The SEC and the CFTC have both entered into a co-operative agreement with the futures and securities self-regulatory organisations regarding the joint in-field examinations and sharing of relevant information in a bid to improve the efficiency and effectiveness of securities law enforcement in the US. ${ }^{21}$ This agreement provides, on a voluntary basis, the opportunity for the SEC and the self-regulatory organisations to review each other's work papers and to share and exchange certain work papers or final investigation reports on any suspected market abuse and/or securities law violations. Likewise, the SEC and the CFTC have both proposed to operate a Joint Advisory Committee, a Joint Agency Enforcement Task Force, a Joint Information Technology Task Force and a joint cross-agency training programme for their staff members. ${ }^{22}$ This is aimed at increasing the sharing of relevant information and/or market surveillance data to enhance enforcement and market oversight by developing solutions to emerging and ongoing regulatory risks in the futures and securities markets. ${ }^{23}$

Furthermore, the SEC has forged a co-operation agreement with the Intermarket Financial Surveillance Group (the IFSG ${ }^{24}$ to enhance and expand co-operation among all the self-regulatory organisations and the SEC in order to combat market abuse in both securities and futures markets. This co-operative agreement has to date increased the financial surveillance and investigation of illicit trading activities by the SEC, self-regulatory organisations and other regulatory agencies in the US and abroad.

The SEC is a member of the International Organisation of Securities Commissions (the IOSCO) and has further adopted and signed international co-operative agreements (Memoranda of Understanding) with regulators and self-regulatory organisations in various foreign countries to discourage and combat illegal cross-border securities violations. ${ }^{25}$ The SEC has also entered into approximately 20 bilateral enforcement Memoranda of Understanding with countries in other jurisdictions to enhance its ability to gather the relevant foreign-based information necessary to any ongoing investigation or prosecution regarding securities law violations. ${ }^{26}$ Although these MOUs are non-binding statements of intent between like-minded regulators, the SEC has fairly managed to utilise them to track and combat market abuse practices which are perpetrated in other countries. ${ }^{27}$

\footnotetext{
${ }^{16}$ Generally see the FSB Annual Report 20114 99-101; the FSB Annual Report 20133 128-130; Chanetsa Business Report 26 April 2004; see further Pretorius and Another v Natal South Sea Investment Trust 417; Blincoe (2001) <http://www.theregister.co.uk /2001/05/23/datatec_directors_pay_up/> (accessed 03-03-2014) \& Barron (2014) <http://www.timeslive.co.za/Feeds/2014/02/02/greg-draws-a-blank-in-belfort-parallel> (accessed 03-03-2014).

${ }^{17}$ Hopt \& Wymeersch (eds) European Insider Dealing-Law and Practice (1991) 340-361.

${ }^{18}$ Chitimira A Comparative Analysis of the Enforcement of Market Abuse Provisions 230-257.

${ }^{19}$ Chitimira A Comparative Analysis of the Enforcement of Market Abuse Provisions 230-257.

${ }^{20}$ Chitimira A Comparative Analysis of the Enforcement of Market Abuse Provisions 230-257.

${ }^{21}$ Chitimira A Comparative Analysis of the Enforcement of Market Abuse Provisions 230-257.

22 The CFTC \& the SEC "A Joint Report of the SEC and the CFTC on Harmonization of Regulation" Report 16 October 2009 10-11 \& 14-15.

${ }^{23}$ The CFTC \& the SEC Report 16 October 2009 10-11 \& 14-15.

${ }^{24}$ The IFSG was formed in 1987 as an independent body comprising the self-regulatory organisations of the US's securities and commodities exchanges.

${ }^{25}$ The countries include the United Kingdom (the UK), Japan, Italy, Brazil, Switzerland, Netherlands, France, Mexico and Canada. See Hopt \& Wymeersch European Insider Dealing 354.

${ }^{26}$ These bilateral Memoranda of Understanding (MOUs) are largely used by the SEC to share bank or audit work papers, Internet service provider information, brokerage records, beneficial ownership records and other relevant information regarding the investigation and enforcement of illicit securities law violations. See s 24(d) read with subsection (f) of the Securities Exchange Act of 193415 USC 78i(a)(2)-(5) (2006) as amended by PL-111-257 (approved 05-10-2010), hereinafter referred to as the Securities Exchange Act, which allows the SEC to keep confidential any information it obtains from similar foreign regulatory bodies or self-regulatory organisations. Furthermore, the IOSCO Multilateral MOU permits the SEC to share with other regulatory bodies elsewhere specific information relating to an ongoing civil, administrative or criminal investigation of cross-border market abuse cases. This implies that the SEC may rely on other foreign regulatory bodies to investigate any suspected cross-border securities law contraventions and to assist it where necessary with information which could be used in a criminal prosecution. See Hopt \& Wymeersch European Insider Dealing 351.

${ }^{27}$ See for example SEC v Levine (1986) 86 Civ 3726 (SDNY) (RO), where the SEC managed to track Levine's insider trading activities involving securities of about 54 companies and other illicit trading in securities relating to secret accounts and in the names of Panamanian corporations located in the
} 
As is the position in the US, ${ }^{28}$ the FSB also polices the general enforcement of securities laws by other regulatory bodies such as the JSE and the Takeover Regulation Panel (the TRP) ${ }^{29}$ in South Africa. This prima facie suggests that the FSB has some co-operation relationship with other local regulatory bodies regarding the enforcement of such laws in South Africa. Although the degree or extent of the effectiveness of such co-operation relationship is unclear, the FSB has to date managed to obtain some settlements and to investigate market abuse cases referred to it by other self-regulatory organisations like the JSE. ${ }^{30}$ However, unlike the position in the US, ${ }^{31}$ it is uncertain whether the FSB has entered into any binding co-operation agreements with specific local self-regulatory organisations like the SRP to combat market abuse practices in the South African financial markets. ${ }^{32}$

The FSB has reportedly entered into co-operation agreements with the SEC and the Financial Services Authority (the FSA) of the US and the UK respectively ${ }^{33}$ for the purposes of curbing cross-border market abuse activities. While this is a positive attempt to combat and reduce all potential cross-border market abuse practices as much as possible, relatively minimal success has been achieved in relation to the utilisation of such co-operation agreements in South Africa to date. ${ }^{34}$ In other words, it remains uncertain whether such co-operation agreements have been fully implemented to improve the detection, investigation and prosecution of all possible unscrupulous trading practices in the relevant financial markets in South Africa and elsewhere. ${ }^{35}$ One can therefore ascribe this inconsistent enforcement of cross-border market abuse laws to the low level of co-operation between the FSB and similar bodies in other jurisdictions. ${ }^{36}$ Nonetheless, this flaw could be corrected if the Financial Markets Act's new provision which now empowers the FSB to assist foreign regulators with investigations pertaining to any cross-border market abuse cases is consistently enforced. ${ }^{37}$

\subsection{Adoption and Establishment of a Good Enforcement Ethics Culture}

As several other countries, the US has made numerous efforts to develop a strong anti-market abuse culture among the relevant persons in all its securities and financial markets. Various methods like the use of civil, criminal and administrative sanctions have been employed to discourage market abuse practices in the US. ${ }^{38}$

Apart from relying on appropriate sanctions as earlier stated, the US employs other methods like incentives and bounty rewards to encourage all persons to report any suspected illicit trading practices to the SEC or other relevant enforcement agencies. ${ }^{39}$ Furthermore, in the wake of the Enron scandal, the US introduced more incentives and whistleblower immunity provisions to enable all persons with information regarding securities market manipulation, insider trading or other market abuse practices to register such information with the SEC without any fear of reprisals or victimisation. ${ }^{40}$

Bahamian branch of Bank Leu International Limited. The SEC was, through the help of other foreign regulators, able to detect and identify Levine as the beneficial owner of these accounts and he was consequently charged with insider trading. See further SEC v Kerherve (1988) No 88 Civ 0227 (SDNY); Hopt \& Wymeersch European Insider Dealing 348-351.

${ }_{28}^{28}$ See related comments above.

${ }^{29}$ See ss 196; 201 \& 202 of the Companies Act 71 of 2008, hereinafter referred to as the Companies Act 2008.

30 See the FSB Annual Report 2011 99-101; the FSB Annual Report 2013 128-130; Blincoe (2001) <http://www.theregister.co.uk /2001/05/23/datatec_directors_pay_up/> (accessed 03-03-2014) \& Barron (2014) <http://www.timeslive.co.za/Feeds/2014/02/02/greg-draws-a-blank-inbelfort-parallel> (accessed 03-03-2014).

${ }^{31}$ See related comments above.

${ }^{32}$ There are no self-regulatory organisations such as those in the US that are specifically and statutorily empowered to supplement the FSB's efforts to enforce and combat commodities-based market abuse activities in South Africa and elsewhere. See the relevant provisions under Chapter X of the Financial Markets Act.

${ }^{33}$ See Loubser (2006) 24-27 <http://www.jse.co.za/public/insider/JSEbooklet.pdfs (accessed 03-03-2014); see further related comments and discussion by the JSE (2013) 24-26 <http://www.jse.co.za/Libraries/JSE_Regulatory_Environment_Insider_Trading /InsiderTrading_Booklet.sflb.ashx> (accessed 03-032014).

${ }^{34}$ See the FSB Annual Report 2011 99-101 \& the FSB Annual Report 2013 128-130 which inter alia reveals that relatively few market abuse cases were successfully investigated, settled and/or prosecuted by the relevant enforcement authorities in South Africa to date.

${ }_{35}^{35}$ See the FSB Annual Report 2011 99-101 \& the FSB Annual Report 2013 128-130 which shows that relatively few cross-border market abuse cases were successfully investigated, settled and/or prosecuted by the relevant enforcement authorities in South Africa to date.

${ }^{36}$ See related comments by Chitimira A Comparative Analysis of the Enforcement of Market Abuse Provisions 421-496; 230-257.

${ }^{37}$ See $s 84(2)(b)$.

${ }^{38}$ See related comments in paragraph 1 read with paragraphs $2.1 \& 2.2$ above.

${ }^{39}$ The SEC may pay bounty rewards of up to $30 \%$ of the civil compensatory penalties recovered to all bona-fide informants. See $s 21 \mathrm{~F}$ of the Securities Exchange Act; also see Palmiter Securities Regulation: Examples and Explanations (2005) 370.

${ }^{40}$ S 21F of the Securities Exchange Act; s 922 of the Dodd-Frank Wall Street Reform and Consumer Protection Act of 2010, Public Law 111-203, 124 Stat.1376 (12 USC; s 5301 et seq.), hereinafter referred to as the Dodd-Frank Act \& ss 806 \& 406 of the the Public Company Accounting Reform and Investor Protection Act of 2002 Public Law 107-204, 116 Stat 745 (as codified in scattered sections of 15; 28 USC), hereinafter referred to as the SarbanesOxley Act which requires all issuers of securities and companies to disclose their code of ethics to detect reporting violations and to ensure compliance and 
The US also tightened and improved its corporate governance laws through the Sarbanes-Oxley Act ${ }^{41}$ to discourage and avoid a recurrence of the Enron, World Com and Arthur Andersen cases. ${ }^{42}$ The Sarbanes-Oxley Act, for instance, prohibits a public company to give a personal loan directly or indirectly to a director or an executive officer of that company in order to discourage fraud and insider trading. ${ }^{43}$ In addition, this Act provides some guidelines on the supervision of the relationship between issuers and auditors to prevent market abuse practices. ${ }^{44}$ Moreover, the Sarbanes-Oxley Act introduced the Public Company Accounting Oversight Board to supervise the activities of the accounting profession in order to combat fraud and other market abuse practices.

Moreover, the US's market abuse regime is based on the so-called multi-functional regulatory model. This multi-functional regulatory model entails that the federal securities law enforcement and regulatory authority does not rest on the SEC alone. ${ }^{45}$ Thus, apart from the SEC, other self-regulatory organisations also have the authority to make their own rules and to enforce the federal securities laws. ${ }^{46}$ As a result, the US has so far been able to investigate and prosecute a number of market abuse cases. ${ }^{47}$

In addition to the enforcement by the SEC, the DOJ or the self-regulatory organisations, the US's market abuse regime allows the prejudiced persons to bring the so-called class actions and claim their damages directly from the offenders in private litigation. This parallel enforcement permits the imposition of multiple sanctions (civil, criminal or administrative penalties) on a certain defendant in a private litigation or in the SEC and/or the DOJ enforcement action. ${ }^{48}$ It is worth noting that during the period between 2004 and 2005, the civil monetary penalties awarded in the SEC enforcement actions and private class actions of the affected persons ranged from about $\$ 5,3$ billion to $\$ 11,5$ billion. ${ }^{49}$ In many instances, the SEC's enforcement actions were accompanied by a private class action. For example, in the World Com scandal, a parallel private settlement was approximately \$6, 2 billion. Furthermore, in 2005 alone, private class actions for market abuse violations produced settlements between $\$ 3,5$ billion and $\$ 9,7$ billion. ${ }^{50}$

A considerable number of methods are also used to prevent market abuse practices in South Africa. In other words, South Africa has made some significant efforts to promote and build a good anti-market abuse culture among all the relevant persons in both regulated and unregulated financial markets. As in the US, ${ }^{51}$ South Africa relies on civil, criminal, and administrative sanctions to deter and discourage unscrupulous persons from engaging in market abuse activities. ${ }^{52}$ Nevertheless, unlike the position in the US, ${ }^{53}$ the Financial Markets Act's market abuse civil sanctions are only limited to cases involving insider trading. ${ }^{54}$ Furthermore, apart from the workshops, seminars, presentations and the JSE's Insider Trading Booklet, no other measures were employed by the FSB or other enforcement agencies to increase awareness and prevent market abuse activity in the South African financial markets. ${ }^{55}$ Moreover, the South African legislature did not employ other methods like incentives, bounty rewards and whistle-blower immunity to encourage informants to voluntarily report all suspected market abuse activities to the FSB or other relevant enforcement authorities. ${ }^{56}$ It is submitted in line

fairness in the US's securities markets. Also see Mossos "Sarbanes-Oxley goes to Europe: A Comparative Analysis of United States and European Union Corporate Reforms after Enron" 2004 Currents International Trade Law Journal 9-11.

${ }^{41}$ This Act requires all companies registered with the SEC to comply with its anti-market abuse provisions. See s 406(c) of the Sarbanes-Oxley Act.

${ }^{42}$ Mossos 2004 Currents International Trade Law Journal 9-11; Palmiter Securities Regulation 390-392.

${ }^{43} S$ 402(a) read with s 306(a) of the Sarbanes-Oxley Act.

${ }^{44}$ The Sarbanes-Oxley Act requires all the SEC filings to provide accurate and detailed financial information. See s 302 \& ss 201 to s 209 . The SarbanesOxley Act further requires all companies to develop their own standards or measures (code of ethics) that are designed to deter all persons from engaging in illicit trading activities. See ss 406 \& 407.

${ }^{45}$ It comprises other enforcement agencies like the CFTC, the DOJ, the Federal Reserve Board and other self-regulatory organisations. See related analysis in paragraph 2.2 above.

${ }^{46}$ This has been so crucial to the effectiveness of the US's anti-market abuse laws in that the SEC as well as other regulatory bodies may take any appropriate enforcement action against the market abuse offenders.

${ }_{47}$ For instance, see SEC v Texas Gulf Sulphur Company (1968) 401 F2d 833 (2d Cir); Dirks v SEC (1983) 463 US 646 646-655; Chiarella v United States (1980) 445 US 222; US v Martha Stewart and Peter Bacanovic (2006) 433 F3d 273; SEC v Galleon Management \& others (2009) 09 Civ 8811(SDNY); SEC v Arthur J Cutillo \& others (2009) 09 Civ 9208 (SDNY) \& SEC v Anthony Fareri \& others (2009) 09 Civ 80360 (SDFla).

${ }^{48}$ See SEC v Palmisiano (1998) 135 F3d 860 (2d Cir) the court held that the offender was guilty of defrauding clients in a false investment scheme and sentenced him to fifteen years in jail and to pay $\$ 3,8$ million restitution to the actual prejudiced persons (in private litigation) plus $\$ 700000$ criminal fines. The same offender was also liable to disgorge profits of $\$ 9,2$ million plus interest and to pay a $\$ 500000$ civil penalty to the SEC. See further Palmiter Securities Regulation 440-441; 459-461.

${ }^{49}$ Coffee "Law and the Market: The Impact of Enforcement" 2007 University of Pennsylvania Law Review 229 230-311.

${ }^{50}$ Coffee 2007 University of Pennsylvania Law Review 230-311.

${ }^{51}$ See related comments above \& in paragraphs $1 ; 2.1 \& 2.2$ above.

${ }^{52}$ See related comments above \& in paragraphs $1 ; 2.1 \& 2.2$ above.

${ }^{53}$ See related comments above \& in paragraphs $1 ; 2.1 \& 2.2$ above.

${ }^{54}$ See $s$ 82 read with ss $78 ; 80 ; 81$ \& 84.

${ }_{55}^{55}$ See related comments by Chitimira A Comparative Analysis of the Enforcement of Market Abuse Provisions 421-496.

${ }^{56}$ See related comments by Chitimira A Comparative Analysis of the Enforcement of Market Abuse Provisions 421-496. 
with the position in the US, ${ }^{57}$ that the Financial Markets Act should be amended to provide specific market abuse whistleblower immunity provisions ${ }^{58}$ for the purposes of encouraging all persons to report market abuse activities to the FSB and/or other relevant enforcement authorities in South Africa.

Moreover, in contrast to the US's multi-functional regulatory model, ${ }^{59}$ South Africa gives the FSB the main responsibility of enforcing the market abuse provisions. ${ }^{60}$ In addition, other self-regulatory bodies like the JSE may only refer any suspected market abuse activities to the FSB for further investigations. ${ }^{61}$ Furthermore, there is no express statutory private right of action for the affected persons to claim their damages directly from the offenders in South Africa. ${ }^{62}$

\section{Concluding Remarks}

The impropriety of market abuse in the US is generally accepted by the public, judiciary, market participants and all the relevant stakeholders in that country both at a State and federal level..$^{63}$ This is supported, in part, by the fact that the regulation and enforcement of the market abuse prohibition is a co-operative (joint) effort involving the SEC, private litigants, self-regulatory organisations, the CFTC and the DOJ at a federal level ${ }^{64}$ as well as the relevant financial or corporation departments at the states level.

On the contrary, the most important characteristic of the regulatory and enforcement framework in the US, namely a coordinated (joint) effort between the courts, self-regulatory organisations and the SEC 65 to combat market abuse and other illicit practices is relatively minimal or absent in South Africa probably due to the differences in relation to the financial markets sizes and enforcement approaches. ${ }^{66}$ In other words, unlike the position in the US, ${ }^{67}$ the South African market abuse regime relies mainly on the FSB to police and enforce the market abuse ban. ${ }^{68}$ Nevertheless, this method has not been consistently employed to obtain more settlements and prosecutions in cases involving market abuse in South Africa to date. ${ }^{69}$ Given this current status quo, it is submitted that the FSB should enter into specific binding co-operation agreements with more local self-regulatory organisations such as the JSE and the TRP to enhance the combating of market abuse practices in the South African financial markets. It is further submitted that the Financial Markets Act should be amended to enact a provision that expressly empowers the FSB to cooperate with other local regulatory bodies such as the JSE and the TRP in order to improve the enforcement of the market abuse prohibition in South Africa. In line with this, it is recommended that the provisions of the Financial Markets Act which now empowers the FSB to assist foreign regulators with investigations pertaining to any cross-border market abuse cases should be consistently employed to prevent and curb cross-border market abuse practices in South Africa. ${ }^{70}$

It is also recommended that the Financial Markets Act should be amended to explicitly provide a statutory private right of action for the aggrieved or prejudiced persons to claim their market abuse damages directly from the offenders. Moreover, the Financial Markets Act should be amended to introduce a specific commodities-based anti-market abuse

\footnotetext{
${ }^{57}$ See related comments above \& in paragraphs $1 ; 2.1 \& 2.2$ above.

${ }^{58}$ Notably, although s 159 of the Companies Act 2008; the Protected Disclosures Act 26 of 2000; s 9 of the South African constitution \& the Promotion of Equality and Prevention of Unfair Discrimination Act 4 of 2000 can be employed to protect shareholders, directors and other employees from occupational reprisals, there are no specific provisions in the Financial Markets Act that can be used to encourage and/or protect market abuse whistle-blowers from such reprisals.

${ }^{59}$ See related comments above.

${ }^{60}$ Although other regulatory bodies like the JSE, the Directorate of Market Abuse (the DMA), the DPP, the Appeal Board (the AB), the Enforcement Committee (the EC) and the TRP are also involved in the enforcement of the securities and market abuse laws, there are no regulatory bodies or selfregulatory organisations other than the FSB that are expressly and statutorily empowered to make their own rules for the purposes of enforcing or combating market abuse practices in South Africa. See the relevant provisions under Chapter X of the Financial Markets Act.

${ }^{61}$ Accordingly, the FSB may investigate such matters and/or refer criminal matters to the DPP for prosecution or to the EC for further administrative action.

${ }^{62}$ See the relevant provisions under Chapter $X$ of the Financial Markets Act.

${ }^{63}$ See Steinberg 2003 The International Lawyer 169-171.

${ }^{64}$ In other words, the prevalent attitudes in the US favour a rigorous enforcement of the market abuse prohibition. See paragraphs 2.1; 2.2; \& 2.3 above; SEC v Sargent (2000) 229 F 3d 68-75 (1st Cir) which display the determination of the judiciary in enforcing insider trading provisions by upholding convictions based on circumstantial evidence. See s 32(a) of the Securities Exchange Act; also see Bergmans Inside Information and Securities Trading: A Legal and Economic Analysis of the Foundations of Liability in the US and the European Community (1991) 41-60.

${ }^{65}$ This is the so-called multi-functional regulatory approach; also see paragraphs $2.1 ; 2.2 ; \& 2.3$ above.

${ }^{66}$ See further related analysis by Chitimira A Comparative Analysis of the Enforcement of Market Abuse Provisions 421-496; the FSB Annual Report 2011 99-101; the FSB Annual Report 2013 128-130 which shows that very few successful prosecutions or civil claims have been obtained to date, especially in the courts \& related remarks in paragraphs $2.1 ; 2.2 ; \& 2.3$ above.

${ }^{67}$ See related comments above \& in paragraph 2.3 above.

${ }^{68}$ See related comments above \& in paragraph 2.3 above.

${ }^{69}$ See related comments in paragraph 2.1 read with paragraphs 2.2 \& 2.3 above

${ }^{70}$ See related comments in paragraph 2.2 above.
} 
enforcement commission or a regulatory body like the CFTC, ${ }^{71}$ to deal effectively and exclusively with the commoditiesbased market manipulation violations in South Africa.

Additionally, the FSB should be statutorily mandated to assist the DPP and the relevant courts with the necessary information regarding ongoing market abuse cases in South Africa, by assigning certain persons with the relevant expertise to assist the DPP and/or the relevant courts in the prosecution of such cases in South Africa. It is also suggested that the Financial Markets Act should be reviewed to enact provisions that mandate companies and all the relevant persons to have anti-market abuse codes of conduct and to appoint anti-market abuse compliance officers so as to prevent market abuse activities in South Africa. It is further submitted that the legislature should consider enacting specific provisions which empower the FSB and the JSE to jointly form, fund, and operate a Joint Market Abuse Advisory Committee that would be tasked with considering and developing solutions to emerging and ongoing market abuse issues of common interest involving commodity and commodity derivatives and futures or securities traded in both the regulated and over the counter markets in South Africa. In other words, the afore-mentioned Joint Market Abuse Advisory Committee should identify emerging regulatory risks, assess and quantify their implications for investors and other market participants, and recommend possible solutions to the FSB and the JSE.

Furthermore, it is suggested that the legislature should consider enacting specific provisions which empower the FSB, the TRP, the JSE and other relevant stakeholders to create a Joint Anti-Market Abuse Enforcement Task Force in order to harness synergies from shared market surveillance data, to improve market oversight, to enhance enforcement and to reduce duplicative regulatory burdens and/or balkanisation. The Joint Anti-Market Abuse Enforcement Task Force should prepare and offer training programmes for the employees of all the relevant enforcement authorities, develop practical market abuse investigation and enforcement measures, and timeously coordinate the sharing of relevant market abuse information. Moreover, the Joint Anti-Market Abuse Enforcement Task Force should oversee the general execution of the day-to-day duties by the employees of all the relevant enforcement agencies to enhance the enforcement of the market abuse ban in South Africa.

It is also submitted, as is the position in the US, ${ }^{72}$ that regulatory agencies such as the FSB and the JSE should establish a Joint Market Abuse Cross-Agency Training Programme for their employees to increase the enforcement of the market abuse provisions in South Africa. This could be achieved by developing a training programme to increase the consistent and/or regular sharing of relevant information and rotating of employees between the FSB and the JSE. This programme, could each year, give the employees of both the FSB and the JSE the opportunity to work at the other agency temporarily for a specified period of time to enhance greater collaboration and coordination between these two agencies.

Lastly, it is recommended, as is the position in the US, ${ }^{73}$ that the FSB and the JSE should consider developing a Joint Market Abuse Information Technology Task Force to link their relevant information pertaining to on-going market abuse investigations if they consider such information to be jointly useful and/or in the public interest. This could promote transparency and facilitate the use and understanding of such information by providing a comprehensive, consolidated database on persons and entities investigated by both the FSB and the JSE in order to combat market abuse activities in the South African regulated financial markets.

\section{References}

Books

Arshadi N \& Eyssell TH The Law and Finance of Corporate Insider Trading: Theory and Evidence (Kluwer Academic Publishers Massachusetts 1993)

Ashe TM \& Counsell L Insider Trading: The Tangled Web (Fourmat Publishing London 1990)

Avgouleas E The Mechanics and Regulation of Market Abuse: A legal and Economic Analysis (Oxford University Press Oxford 2005) Bainbridge SM Corporation Law and Economics (Foundation Press New York 2002)

Bergmans B Inside Information and Securities Trading: A Legal and Economic Analysis of the Foundations of Liability in the US and the European Community (Graham \& Trotman London 1991)

Beuthin RC \& Luiz SM Beuthin's Basic Company Law 3rd ed (Butterworths Durban 2000)

Hazen TL The Law of Securities Regulation: Handbook Series Student Edition (West Publishing Company St Paul, MN 1985)

Hazen TL Federal Securities Law $2^{\text {nd }}$ ed (Federal Judicial Center United States of America 2003)

Hopt KJ \& Wymeersch E (eds) European Insider Dealing - Law and Practice (Butterworths London 1991)

Lyon GJ \& Du Plessis JJ The Law of Insider Trading in Australia (The Federation Press Sydney 2005)

Palmiter AR Securities Regulation: Examples and Explanations $3^{\text {rd }}$ ed (Aspen Publishers New York 2005)

\footnotetext{
${ }^{71}$ See related remarks in paragraph 2.2 above.

${ }^{72}$ See related remarks in paragraph 2.2 above.

${ }^{73}$ See related remarks in paragraph 2.2 above.
} 
Swan EJ Market Abuse Regulation $1^{\text {st }}$ ed (Oxford University Press United States of America 2006)

Journal articles

Bhattacharya U \& Daouk H "The World Price of Insider Trading" 2002 Journal of Finance 75-108

Botha D "Control of Insider Trading in South Africa: A Comparative Analysis" 1991 SA Merc LJ 1-18

Botha D "Increased Maximum Fine for Insider Trading: A Realistic and Effective Deterrent?" 1990 SALJ 504-508

Carlton DW \& Fischel DR "The Regulation of Insider Trading" 1983 Stanford Law Review 857-895

Cassim R "An Analysis of Market Manipulation under the Securities Services Act 36 of 2004 (Part 1)" 2008 SA Merc LJ 33-60

Cassim R "An Analysis of Market Manipulation under the Securities Services Act 36 of 2004 (Part 2)" 2008 SA Merc LJ 177-199

Coffee JC "Law and the Market: The Impact of Enforcement" 2007 University of Pennsylvania Law Review 229-311

Dolgopolov S "Insider Trading and the Bid-Ask Spread: A Critical Evaluation of Adverse Selection in Market Making" 2004 Capital University Law Review 83-180

Dooley MP "Enforcement of Insider Trading Restrictions" 1980 Virginia Law Review 1-83

Friedman HM "The Insider Trading and Securities Fraud Enforcement Act of 1988" 1990 North Carolina Law Review 465-494

Gilson RJ \& Kraakman RH "The Mechanisms of Market Efficiency" 1984 VA.L.REV 549-644

Henning JJ \& Du Toit S "The Regulation of False Trading, Market Manipulation and Insider Trading" 2000 Journal for Juridical Science $155-165$

Horwich A "The Origin, Application, Validity and Potential Misuse of Rule 10b5-1" 2007 The Bus. Lawyer 913-954

Jooste R "A critique of the insider trading provisions of the 2004 Securities Services Act" 2006 SALJ 437-460

Kaswell SJ "An Insider's View of the Insider Trading and Securities Fraud Enforcement Act" 1989 Bus.Law 145-180

Knepper ZT "Examining the Merits of Dual Regulation for Single-Stock Futures: How the Divergent Insider Trading Regimes for Federal

Futures and Securities Markets Demonstrate the Necessity for (and Virtual Inevitability of) Dual CFTC-SEC Regulation for Single-

Stock Futures" 2004 Pierce Law Review 33-47

Langevoort DC \& Gulati GM "The Muddled Duty to Disclose under Rule 10b-5" 2004 Vand L Rev 1639-1680

Lastra RM "The Governance Structure for Financial Regulation and Supervision in Europe" 2003 Colum J Eur L 49-68

Luiz SM "Insider Trading Regulation - If at First You Don't Succeed..." 1999 SA Merc LJ 136-151

Luiz SM "Market Abuse and the Enforcement Committee" 2011 SA Merc LJ 151-172

Osode PC "The new South African Insider Trading Act: Sound law reform or legislative overkill?" 2000 Journal of African Law 239-263

Osode PC "The Regulation of Insider Trading in South Africa: A Public Choice Perspective" 1999 African Journal of International and Comparative Law 688-708

Markham JW "'Front-Running'-Insider Trading under the Commodity Exchange Act" 1988 Cath.U.Review 69-127

Mossos E "Sarbanes-Oxley goes to Europe: A Comparative Analysis of United States and European Union Corporate Reforms after Enron" 2004 Currents International Trade Law Journal 9-22

Nelemans M "Redefining Trade-Based Market Manipulation" 2008 Valparaiso University Law Review 1169-1220

Osode PC "The new South African Insider Trading Act: Sound law reform or legislative overkill?" 2000 Journal of African Law 239-263

Pearce BD "Broadening Actual Damages in the Context of the Commodities Exchange Act" 2007 Journal of Law and Policy 449-483

Pearson TC "When Hedge Funds Betray A Creditor Committee's Fiduciary Role: New Twists on Insider Trading in the International Financial Markets" 2009 Review of Banking \& Financial Law 165-220

Ryan L "Rule14e-3's Disclose or Abstain Rule and Its Validity under Section 14(e)" 1991 U. Cin. Law Review 449-465

Steinberg MI "Insider Trading Regulation-A Comparative Perspective" 2003 The International Lawyer 153-171

Tomasic R "Insider Trading in the USA and United Kingdom" 1991 Australian Studies in Law, Crime and Justice Series 31-39

Van Deventer G "New watchdog for insider trading" 1999 FSB Bulletin 2-3

Van Deventer G "Harnassing Administrative Law in Encouraging Compliance" 2009 FSB Bulletin 3-4

Case law

South Africa

Pretorius and Another v Natal South Sea Investment Trust 19653 SA 410 (W)

United States of America

Cady, Roberts and Company [1961-1964 Transfer Binder] CCH Fed Sec L Rep 76. 803

Chiarella v United States (1980) 445 US 222

Dirks v SEC (1983) 463 US 646

FMC Corp v Boesky (1988) 852 F2d 981 (7th Cir)

FMC Corp v Boesky (1987) 673 F2d 272 (ND I11)

In re Enron Corporation Securities Derivative and "ERISA"Litigation Plaintiffs v Enron Corp Oregon Corporation Defendants (2006) WL 2795321 (SD Tex)

In re World Com Inc Sec. Litig (2005) 388 F Supp 2d 319 (SDNY)

Santa Fe Industries Inc v Green (1977) 430 US 462

SEC $v$ Anthony Fareri \& others (2009) 09 Civ 80360 (SDFla)

SEC v Arthur J Cutillo \& others (2009) 09 Civ 9208 (SDNY) 
SEC v Boesky (1986) 86 Civ 8767

SEC v Galleon Management \& others (2009) 09 Civ 8811(SDNY)

SEC v Kerherve (1988) No 88 Civ 0227 (SDNY)

SEC $v$ Levine (1986) 86 Civ 3726 (SDNY) (RO)

SEC v One or more purchasers of call options for the Common Stock of CNS INC (2006) US District Court 3004875 WL (EDPa)

SEC v Palmisiano (1998) 135 F3d 860 (2d Cir)

SEC v Sargent (2000) 229 F 3d 68-75 (1st Cir)

SEC v Texas Gulf Sulphur Company (1968) 401 F2d 833 (2d Cir)

SEC $v$ WorldCom Inc (2003) 02 Civ 4963(JSR)

SEC v Yun (2003) 327 F3d 1263 (11 th Cir)

The Trane Company v O'Connor Securities (1983) 561 F Supp 301 (SDNY)

United States v Brown (1933) 5 F Supp 81 (SDNY)

United States v Chestman (1991) 947 F2d 551 (2d Cir)

United States v Falcone [2001 Transfer Binder] 91489 Fed Sec L Rep CCH (2d Cir)

United States v O'Hagan (1997) 117 (SCt) 2199

US v Martha Stewart and Peter Bacanovic (2006) 433 F3d 273

US v Milken (1990) 759 F Supp 109 (SDNY)

US v Mulheren (1991) 938 F2d 364 ( $\left.2^{\text {nd }} \mathrm{Cir}\right)$

US v O’Hagan (1997) 521 US 642

Legislation

South Africa

Companies Act 71 of 2008

Consumer Protection Act 68 of 2008

Financial Markets Act 19 of 2012

Financial Institutions (Protection of Funds) Act 28 of 2001

Promotion of Equality and Prevention of Unfair Discrimination Act 4 of 2000

Protected Disclosures Act 26 of 2000

United States of America

Commodity Exchange Act of 19367 USC 1 et seq. (1994)

Commodities Futures Modernization Act 2000 Public Law 106-554, 114 Stat.2763A-365

Commodity Futures Trading Commission Act of 1974 Public Law 93-64, 88 Stat 1398

Derivatives Market Manipulation Prevention Act of 2009

Dodd-Frank Wall Street Reform and Consumer Protection Act of 2010, Public Law 111-203, 124 Stat.1376 (12 USC; s 5301 et seq.)

Insider Trading and Securities Fraud Enforcement Act of 1988 Public Law 100-704, 102 Stat 4677

Insider Trading Sanctions Act of 1984 Public Law 98-376, 98 Stat.1264 (1984)

International Securities Enforcement Cooperation Act of 1990

Investment Advisors Act of 1940

Investment Company Act of 1940

Public Company Accounting Reform and Investor Protection Act of 2002 Public Law 107-204, 116 Stat 745 (15; 28 USC)

Public Utility Holding Company Act of 1935

Racketeer Influenced and Corrupt Organization Act of 1970

Securities Act of 1933 Public Law 2248 Stat 7415 USC77a-77mm (1994)

Securities Act of 1933, Public Law 2248 Stat.74 15 USC 77a-77mm et seq. (2000)

Securities Act of 193315 USC 77q(a) (2006) as amended by PL-111-229 (approved 11-08-2010)

Securities Exchange Act of 1934 Public Law 73-291, 48 Stat 88115 USC 78a-78II

Securities Exchange Act of 193415 USC 78i(a)(2)-(5) (2006) as amended by PL-111-257 (approved 05-10-2010)

Securities Exchange Act Release Number 43154 [2000 Transfer Binder] Fed Sec L Rep CCH 86.319

Trust Indenture Act of 1939

Commissions, committees and reports

South Africa

Financial Services Board Annual Report 2011

Financial Services Board Annual Report 2013

United States of America

The Commodity Futures Trading Commission \& the United States Securities and Exchange Commission "A Joint Report of the SEC and the CFTC on Harmonization of Regulation" Report 16 October 2009 
Thesis and dissertations

Chitimira H A Comparative Analysis of the Enforcement of Market Abuse Provisions (LLD-thesis Nelson Mandela Metropolitan University 2012)

Chitimira H The Regulation of Insider Trading in South Africa: A Roadmap for an Effective, Competitive and Adequate Regulatory Statutory Framework (LLM-dissertation University of Fort Hare 2008)

Conference papers, media releases and other relevant material

Fons RJ \& Rowe TA "The SEC Speaks: Aggressive Enforcement to Intensify in 2011" Morrison \& Foerster Client Alert 09 February 2011 Morrison \& Foerster "Insider Trading" 2010 Year End Review 1

\section{Newspaper reports}

Chanetsa B "Insider Trading is Notoriously Hard to Prosecute" Business Report 26 April 2004

Internet sources

Barron C "Greg Draws a Blank in Belfort Parallel" (2014) <http://www.timeslive.co.za/Feeds/2014/02/02/greg-draws-a-blank-in-belfortparallel> (accessed 03-03-2014)

Blincoe R "Datatec Directors Pay Up on Insider Trading Charges" (2001) <http://www.theregister.co.uk/2001 /05/23/datatec_directors_pay_up/> (accessed 03-03-2014)

Commodity Futures Trading Commission "About the Commodity Futures Trading Commission" (2006) $<$ http://www.cftc.gov/cftcabout.htm> (accessed 07-10-2013)

Department of Justice "US Department of Justice, Fact Sheet: Corporate Fraud Task Force" (2006) <http://www.usdoj.gov.opa/pr/2006/August/06_odag_525.html> (accessed 12-02-2014)

Financial Industry Regulatory Authority "2008 Year in Review and Annual Financial Report" (2008) <http://www.finra.org> (accessed 02 03-2014)

Financial Services Board "Enforcement Committee Actions" Media Release (28-06-2011) <http://www.fsb.co.zal $\mathrm{ftp}: / /$ ftp.fsb.co.za/public/documents/AReport2011.pdf> (accessed 22-11-2013)

Financial Services Board "List of Current Investigations of the Directorate of Market Abuse" Media Release (28-06-2011) $<$ http://www.fsb.co.za/ftp://ftp.fsb.co.za/public/documents/AReport2011.pdf> (accessed 22-11-2013)

Johannesburg Stock Exchange Limited "Insider Trading and other Market Abuses (Including the Effective Management of Pricesensitive Information)" in the Insider Trading Booklet, (2013) <http://www.jse.co.za/Libraries/JSE_Regulatory Environment_Insider_Trading/InsiderTrading_Booklet.sflb.ashx> (accessed 03-03-2014)

Karpoff JM, Lee DS \& Martin GS "The Legal Penalties for Financial Misrepresentation" (2007) <http://www.ssrn.com/abstract=933333> (accessed 28-09-2013)

Loubser R "Insider Trading and other Market Abuses (Including the Effective Management of Price-sensitive Information)" in the Insider Trading Booklet final draft, (2006) <http://www.jse.co.za/public/insider/JSEbooklet.pdf> (accessed 03-03-2014)

Morgan Lewis "2009 Year in Review: SEC and SRO Selected Enforcement Cases and Developments Regarding Broker-Dealers" 2010 $<$ http://www.morganlewis.com/lit_SECandYearlyReviewWP_Jan2010.pdf> (accessed 10-06-2013)

Myburgh A \& Davis B "The Impact of South Africa's Insider Trading Regime: A Report for the Financial Services Board" (25-03-2004) $<$ http://www.genesis-analytics.com/public/FSBReport.pdf> (accessed 09-02-2013)

Saikin G "SEC, DOJ Clarify Cooperation" <http://www.executivelegaladvisor.com/docs/SEC-DOJ-Clarify-Cooperation.htm> (accessed 28-02-2014)

United States Securities and Exchange Commission "SEC, 2006 Performance and Accountability" (2006) Report 8 $<$ http://www.sec.gov/about/secpar/secpar2006.pdf> (accessed 21-02-2014)

United States Securities and Exchange Commission "SEC, 2005 Performance and Accountability" (2005) Report 7 $<$ http://www.sec.gov/about/secpar/secpar2005.pdf> (accessed 21-02-2014)

Van Deventer G "Anti-Market Abuse Legislation in South Africa" (10-06-2008) <http://www.fsb.co.za/public/marketabuse/FSBReport.pdf> (accessed 05-05-2013) 